\title{
PERBANDINGAN KEMAMPUAN PEMAHAMAN KONSEP MATEMATIS MELALUI MODEL PEMBELAJARAN IMPROVE DAN MODEL PEMBELAJARAN LANGSUNG PADA SISWA KELAS VIII SMP NEGERI 30 MUARO JAMBI
}

\author{
Dara Suciati $^{1}$, Risma Simamora ${ }^{2}$, Sri Dewi $^{3}$ \\ Program Studi Pendidikan Matematika, FKIP, Universitas Batanghari ${ }^{1,2,3}$ \\ Jl. Slamet Riyadi No.1 Broni Jambi \\ Email: darasuciati24@gmail.com
}

\begin{abstract}
ABSTRAK
Penelitian ini bertujuan untuk mengetahui kemampuan pemahaman konsep matematis siswa yang dibelajarkan melalui model pembelajaran IMPROVE lebih baik dari pada kemampuan pemahaman konsep matematis siswa dengan model pembelajaran langsung pada kelas VIII SMPN 30 Muaro Jambi tahun ajaran 2017/2018 yang berjumlah 69 siswa. Sedangkan sampelnya adalah kelas VIIA dan VIIB. Instrumen dalam penelitian ini adalah tes tertulis pada materi Sistem Persamaan Linear Dua Variabel. Hasil penelitian diperoleh nilai rata-rata kemampuan pemahaman konsep matematis kelas eksperimen adalah 79,19 dengan simpangan baku 9,83 dan nilai rata-rata kemampuan pemahaman konsep matematis kelas kontrol 61,52 dengan simpangan baku 11,9, serta hasil dari uji hipotesis diperoleh $\mathrm{t}_{\text {hitung }} 1,80$ dan $\mathrm{t}_{\text {tabel }} 1,68$ pada taraf nyata 0,05 . Dari hasil perhitungan tersebut terlihat bahwa $t_{\text {hitung }}$ lebih besar dari $t_{\text {tabel }}$ dengan demikian $\mathrm{H}_{1}$ diterima, artinya kemampuan pemahaman konsep matematis siswa melalui model pembelajaran IMPROVE lebih tinggi daripada kemampuan pemahaman konsep matematis melalui model pembelajaran langsung.
\end{abstract}

\section{Kata kunci:}

Pemahaman Konsep Matematis, Model Pembelajaran IMPROVE, Model Pembelajaran Langsung

\begin{abstract}
This study aims to determine the ability to understand the mathematical concepts of students taught through the IMPROVE learning model better than the ability to understand the mathematical concepts of students with direct learning models in class VIII SMPN 30 Muaro Jambi in the academic year 2017/2018, amounting to 69 students. While the sample is class VIIA and VIIB. The instrument in this study was a written test on the material of the Two Variable Linear Equation System. The results obtained the average value of the ability of understanding the mathematical concepts of the experimental class was 79.19 with a standard deviation of 9.83 and the average value of the ability of understanding the mathematical concepts of the control class 61.52 with a standard deviation of 11.9, and the results of the hypothesis test were obtained tcount 1.80 and t table 1.68 at the significance level of 0.05. From the results of these calculations it can be seen that tcount is greater than ttable thus $\mathrm{Hl}$ is accepted, meaning that the ability to understand students' mathematical concepts through the IMPROVE learning model is higher than the ability to understand mathematical concepts through the direct learning model.
\end{abstract}

Keywords:

Understanding Mathematical Concepts, IMPROVE Learning Model, Direct Learning Model

\section{PENDAHULUAN}

Matematika merupakan salah satu ilmu dasar yang mempunyai peranan penting. Banyaknya kegunaan dari matematika sehari-hari merupakan salah satu alasan mengapa matematika merupakan pelajaran sekolah yang dipandang penting dan dipelajari oleh 


\section{$\pi$ (Phi)}

peserta didik di semua tingkat pendidikan dan pelajaran matematika juga merupakan salah satu sarana dalam membentuk siswa untuk berpikir secara alamiah (Fitriani, 2015)

Mengingat pentingnya peranan matematika, maka keberhasilan belajar matematika setiap sekolah perlu mendapatkan perhatian yang serius. Keberhasilan dalam mempelajari matematika dapat dilihat dari penguasaan siswa terhadap pemahaman konsep,pemecahan masalah, dan komunikasi.

Pemahaman konsep dalam matematika merupakan kemampuan dasar yang harus dimiliki siswa dalam proses belajar mengajar. Pemahaman konsep juga merupakan dasar untuk melanjutkan ke materi yang lainnya. Apabila seorang siswa tidak memahami konsep dasar dalam proses pembelajaran matematika, maka untuk tahap selanjutnya akan lebih sulit. Sebab matematika merupakan mata pelajaran yang saling terkait satu sama yang lainnya dan tidak dapat dipisah-pisahkan serta mengikuti urutan tertentu, hal ini berarti konsep yang satu berkaitan dengan konsep yang lain. Oleh sebab itu, salah satu masalah yang penting diperhatikan dalam proses pembelajaran matematika ialah konsep yang akan ditanamkan pada siswa.

Model pembelajaran IMPROVE dapat membantu mengembangkan kemampuan pemahaman konsep matematis yang terlihat dari 7 aspek yang terdapat pada model ini yaitu: 1) pengenalan konsep; 2) memberikan pertanyaan-pertanyaan metakognitif; 3) latihan memecahkan permasalahan 4) tinjauan ulang dan mengurangi kesulitan; 5) melakukan tes; 6) verifikasi hasil kuis; 7) melakukan pengayaan/perbaikan.

pembelajaran dengan model IMPROVE siswa juga disituasikan untuk belajar berkelompok dalam menyelesaikan masalah-masalah yang ada. Kelompok tersebut terdiri dari siswa yang heterogen. Situasi belajar berkelompok yang heterogen ini dapat menonjolkan interaksi dalam kelompok seperti tanya jawab, tukar pendapat, dan debat antar siswa. Selain dari itu, belajar berkelompok mampu membuat siswa menerima siswa lain yang berkemampuan latar belakang yang berbeda.Judul penelitian ini adalah perbandingan kemampuan pemahaman konsep matematis melalui model pembelajaranIMPROVE dan model pembelajaran langsung pada siswa kelas VIII SMP.

\section{METODE PENELITIAN}

Sesuai dengan permasalahan yang telah dikemukakan sebelumnya, maka jenis penelitian yang digunakan dalam penelitian ini merupakan penelitian eksperimen. Menurut (Sugiyono,2015) metode eksperimen dapat diartikan sebagai metode penelitian yang digunakan untuk mencari pengaruh perlakuan tertentu terhadapyang lain dalam kondisi yang terkendalikan.

Penelitian ini dilakukan terhadap dua kelas,yaitu kelas eksperimen dan kelas kontrol. Pada kelas eksperimen dilakukan model pembelajaran IMPROVE dan pada kelas kontrol menggunakan model pembelajaran langsung

Dalam penelitian ini yang akan dijadikan populasi adalah seluruh siswa kelas VIII SMP Negeri 30 Muaro Jambi yang terdiri dari tiga kelas. Sampel yang digunakan sebanyak dua kelompok sampel yaitu kelompok eksperimen dan kelompok kontrol. Kelompok eksperimen merupakan kelas yang diajarakan dengan model IMPROVE 


\section{$\pi$ (Phi)}

dan kelas kontrol merupakan kelas yang diajarkan dengan model pembelajaran langsung. pengambilan sampel tersebut menggunakan teknik random sampling, yaitu pengambilan smple secara acak dari populasi yang berdistribusi normal tanpa memperhatikan strata yang ada dalam populasi itu (Sugiyono,2015).

Rancangan penelitian yang digunakan dalam penelitian ini adalah posttest-only control design (Sugiyono, 2015). Berikut desain penelitian dari penelitian ini dapat dilihat pada tabel 1 .

Tabel 1. Desain Penelitian

\begin{tabular}{ccc}
\hline Kelas & Treatment & Post-test \\
\hline Eksperimen & $\mathrm{X}$ & $\mathrm{O}_{1}$ \\
Kontrol & - & $\mathrm{O} 2$ \\
\hline
\end{tabular}

Instrumen penelitian adalah alat atau fasilitas yang digunakan oleh peneliti dalam mengumpulkan data agar pekerjaannya lebih mudah dan hasilnya lebih baik, dalam arti lebih cermat, lengkap dan sistematis sehingga lebih mudah diolah Arikunto (2013).

Dengan demikian untuk memperoleh data tentang kemampuan pemahaan konsepmatematika siswa, penulis menggunakan alat pengumpulan data yang berbentuk tes hasil belajar. Tes yang digunakan adalah tes subjektif (uraian) yang diberikan kepada siswa sesudah perlakuan terhadap kelas eksperimen dan kelas kontrol. Data yang dianalis adalah skor hasil tes akhir siswa kelas eksperimen dan kelas kontrol. Setelah data yang diperoleh dilakukan analisis data untuk menguji hipotesis dengan membandingkan skor rata-rata nilai siswa kelompok eksperimen dan kelompok kontrol. Metode statistik yang digunakan adalah uji kesamaan rata-rata dengan uji-t untuk menguji hipotesis dalam penelitian ini. Sebelum analisis dilakukan terlebih dahulu uji normalitas dan uji homogenitas.

Uji normalitas digunakan untuk mengetahui apakah data pada dua kelompok sampel yang diteliti berasal dari populasi yang berdistribusi normal atau tidak. Dalam penelitaian ini, pengujian normalitas menggunakan uji chi kuadrat (chi square).

Membandingkan nilai chi-kuadrat dengan tabel chi-kuadrat dengan taraf signifikan 5\%. Dalam Menarik kesimpulan jika $x^{2}$ hitung $<x^{2}$ tabel maka berdistribusi normal dan jika $x^{2}$ hitung $\geq x^{2}$ tabel maka data tidak berdistribusi normal.Uji homogenitas dilakukan untuk menguji apakah populasi mempunyai varians yang sama atau tidak.

Bila :

$F_{\text {hitung }}<\mathrm{F}_{\text {tabel }}$ : varians nilai kelompok yang dibandingkan homogen.

$F_{\text {hitung }}>F_{\text {tabel }}$ : varians nilai kelompok yang dibandingkan tidak homogen.

Uji hipotesis yang digunakan adalah uji kesamaan dua rata-rata. Uji ini digunakan untuk mengetahui kemampuan pemahaman konsep matematis siswa yang dibelajarkan melalui model pembelajaran IMPROVE lebih baik dari pada kemampuan pemahaman konsep matematis siswa dengan model pembelajaran langsung pada kelas VIII SMPN 30 Muaro Jambi. Berdasarkan hipotesis yang telah dikemukakan, maka uji satu pihak dengan hipotesis statistik:

$H_{0}: \mu_{1} \leq \mu_{2}$

$H_{1}: \mu_{1}>\mu_{2}$

Dimana $\mu_{1}$ dan $\mu_{2}$ adalah nilai rata-rata kemapuan pemahaman konsep matematis siswa dari masing-masing kelompok sampel. untuk menguji apakah skor rata-rata kelas sampel 


\section{$\pi$ (Phi)}

berbeda.

Kriteria pengujiannya : terima $\mathrm{H}_{0}$ jika $t_{\text {hitung }}<t_{1}-\alpha$ dimana $t_{1-\alpha} \alpha$ didapat dari daftar normal baku dengan peluang (1$\alpha)$ dan $\mathrm{dk}=\mathrm{n}_{1}+\mathrm{n}_{2}-2$ dengan $\alpha=0,05$, untuk harga-harga $\mathrm{t}$ yang lain $\mathrm{H}_{0}$ di tolak.

\section{HASIL DAN PEMBAHASAN}

Hasil penelitian ini berupa uji normalitas, uji homogenitas, dan hipotesis. Menguji normalitas data hasil posttest kemampuan pemahaman konsep matematis siswa dikelas eksperimen dan kelas kontrol dapat di lihat pada tabel 13 di bawah ini:

Tabel 2. Uji Normalitas Postest

\begin{tabular}{cccccc}
\hline Kelas Sampel & $\mathbf{N}$ & $\boldsymbol{x}^{2}{ }_{\text {hit }}$ & $\mathbf{X}^{\mathbf{2}}{ }_{\text {tab }} \mathbf{A}=\mathbf{5 \%}$ & Hasil Uji & Ket \\
\hline Ekspeimen & 24 & 6,92 & 7,81 & $\mathrm{X}^{2}{ }_{\text {hit }}<\mathrm{X}^{2}$ tab & Normal \\
Kontrol & 24 & 2,9 & 7,81 & $\mathrm{X}^{2}{ }_{\text {hit }}<\mathrm{X}_{\text {tab }}$ & Normal \\
\hline
\end{tabular}

Berdasarkan keterangan perhitungan pada tabel 13 di atas terlihat bahwa uji normalitas kemampuan pemahaman konsep matematis siswa dikelas eksperimen mempunyai nilai $x^{2}$ hitung sebesar 6,92 lebih rendah dari pada $x^{2}$ tabel sebesar 7,81. Dikelas konstrol kemampuan pemahaman konsep matematis siswa mempunyai nilai $x^{2}$ hitung sebesar 2,992 lebih rendah dari pada $x^{2}$ tabel sebesar 7,81. Sehingga dapat disimpulkan bahwa kelas eksperimen dan kelas kontrol berdistribusi normal.

Menguji homogenitas data asli posttest kemampuan pemahaman konsep matematis siswa kelas eksperimen dan kelas kontrol,perhitungan homogenitas posttest dapat dilihat dibawah ini:

Hipotesis :

$\mathrm{H}_{0}: \sigma_{1}^{2}=\sigma_{2}^{2}$

$\mathrm{H}_{1}: \sigma_{1}^{2} \neq \sigma_{2}^{2}$

Rumus yang digunakan :

$$
F=\frac{\text { varianterbesar }}{\text { varianterkecil }}
$$

$\mathrm{H}_{0}$ diterima jika $\mathrm{F}_{\text {hitung }}<\mathrm{F}_{\text {tabel }} ; \mathrm{F}_{\text {tabel }}=$ $\mathrm{F}_{(1-\alpha)(n a-1) ;(n b-2)}$

$$
\text { Hasil homogenitas tes }
$$

kemampuan pemahaman konsep matematis siswa dikelas eksperimen dan kelas kontrol dapat dilihat pada Tabel 3 berikut ini:

Tabel 3. Uji Homogenitas Varians Data Hasil Post-test Kelas Sampel

\begin{tabular}{ccccccc}
\hline \multicolumn{2}{c}{ Varians } & & $\alpha$ & $F_{\text {hitung }}$ & $F_{\text {tabel }}$ & \multirow{2}{*}{ Keterangan } \\
\hline Eksperimen & Kontrol & & 0,05 & 1,13 & 6,31 & Homogen \\
\hline 90,84 & 141,97 & & 0,05 &
\end{tabular}

Pada tabel 3 di atas terlihat bahwa uji homogenitas Posstest meghasilakn Fhitung sebesar 1,13 dan $F_{\text {tabelsebesar }}$ 6.31. Oleh karena nilai $F_{\text {tabel }}$ lebih kecil dari pada $F_{\text {tabel }}$ Sehingga dapat disimpulkan bahwa kelas eksperimen dan kelas control mempunyai varians yang homogen. perhitungan selengkapnya ada di lampiran 24.

Pengujian hipotesis ini dilakukan dengan uji t, karena data berdistribusi normal dan memiliki varians yang homogen. Hasil perhitungan uji hipotesis dapat dilihat pada Tabel 15 berikut ini:

Tabel 4. Perbandingan Rata-rata Hasil Tes Kemampuan Pemahaman Konsep Matematis Siswa

\begin{tabular}{cccccc}
\hline Kelas & $\mathbf{N}$ & Rata-rata & $\mathbf{t}_{\text {hitung }}$ & dk & $\mathbf{t}_{\text {tabel }}$ \\
\hline Eksperimen & 24 & 80,18 & \multirow{2}{*}{1,80} & \multirow{2}{*}{46} & \multirow{2}{*}{1,68} \\
Kontrol & 24 & 61,52 & & & \\
\hline
\end{tabular}


Berdasarkan tabel diatas diperoleh nilai $t_{\text {hitung }}=1,80$ lebih besar dari $t_{\text {tabel }}=$ 1,68 berarti $\mathrm{H}_{0}$ ditolak atau kemampuan pemahaman konsep matematis siswa yang dibelajarkan dengan model pembelajaran IMPROVE lebih tinggi dari pada kemampuan pemahaman konsep matematis siswa yang dibelajarkan dengan model pembelajaran langsung.

$$
\text { Pembelajaran menggunakan }
$$

model IMPROVE dan model pembelajaran langsung pada kelas eksperimen dan kelas kontrol dilaksanakan berurutan sesuai dengan RPP. Pada proses pembelajaran di kelas eksperimen yang menggunakan model pembelajaran IMPROVE dilakukan dengan membentuk beberapa kelompok yang terdiri dari 4 orang siswa. Setelah berkelompok mereka akan bersama-sama mengerjakan lembar kerja siswa (LKS) dan pada langkah introducing the new concept yang melatih kemampuan pemahaman kosnep matematis siswa,serta metakognitive questioning yang mengkonstruksi pengetahuan siswa. Pada awal pertemuan siswa mengalami beberapa kesulitan dalam mengerjakan LKS. Namun,dengan bimbingan guru mereka dapat memahaminya. Hal ini dikarenakan siswa belum terbiasa dengan proses pembelajaran dimana mereka dituntut untuk dapat memahami sendiri konsep matematika melalui permasalahan yang diberikan. Setelah menyelesaikan pengerjaan LKS salah satu dari perwakilan kelompok diminta untuk menjelaskan hasil diskusi kepada teman-temannya dan teman lain memberikan tanggapan. Adanya tahap siswa mempresentasikan hasil kerjanya dan siswa lain memberikan tanggapan terhadap hasil pekerjaan temannya dapat melatih siswa untuk mengekspresikan

ide-ide matematikanya

Pada proses pembelajaran di kelas kontrol yang menggunakan model pembelajaran langsung proses pembelajaran berjalan seperti biasanya. Pada kelas kontrol guru terlebih dahulu menjelaskan materi dan konsep matematika. Selanjutnya siswa diminta untuk mengerjakan latihan mandiri untuk melihat sampai sejauh mana pemahaman siswa tersebut. Selain itu, berdasarkan nilai posttest diketahui bahwa kemampuan pemahaman konsep matematis siswa di kelas ekperimen selalu lebih tinggi dibandingkan kelas kontrol. Aktivitas siswa pada tahap introducing the new concept, metacognitive questioning, practicing dan obtaining mastery memiliki peran besar dalam pengaruh yang diberikan, hal ini dikarenakan pada tahap inilah siswa mengorganisasikan ide-ide nya untuk memahami materi sehingga memicu berpikir kritis pada siswa dan kemampuan komunikasi siswa dapat lebih dikembangkan. Sementara pada penerapan pembelajaran langsung, siswa hanya menerima informasi ataupun materi yang diberikan oleh guru.

Penelitian ini dilakukan dengan tujuan untuk membandingkan kemampuan pemahaman kosnep siswa yang diajar dengan model IMPROVE (Introducing The New Concept, Metacognitive Questioning, Practicing, Reviewing and Reducing Difficulties, Obtaining Mastery, Verification, Enrichment) dengan model pembelajaran langsung dengan populasi siswa kelas VIII SMP Negeri 30 Muaro Jambi.

Penelitian ini dilaksanakan selama 3 minggu, dimana masing- 


\section{$\pi$ (Phi)}

masing kelas sampel diberikan perlakuan sebanyak 5 pertemuan dengan materi yang sama yaitu Sistem persamaan linear dua variabel. Setelah pelaksanaan pembelajaran pada kelas eksperimen yang menggunakan model IMPROVE dan kelas kontrol yang menggunakan model pembelajaran langsung selama 5 pertemuan,maka di akhir penelitian kedua kelas tersebut diberikan tes akhir (posttest) untuk mengetahui kemampuan pemahaman konsep matematis siswa pada materi sistem persamaan linear dua variabel.Berdasarkan hasil analisis data diperoleh rata-rata nilai posttest pada kelas eksperimen sebesar 80,18 dengan nilai terendah 60, nilai tertinggi 98, dan simpangan baku 9,83. Sedangkan pada kelas kontrol diperoleh rata-rata sebesar 61,52 dengan nilai terendah 43 , nilai tertinggi 91, dan simpangan baku 11,91. Dari data terlihat bahwa rata-rata nilai posttest pada kelas eksperimen lebih tinggi dari kelas kontrol, begitu juga untuk nilai terendah dan nilai tertingginya.

Uji hipotesis terhadap rata-rata skor posttest kemampuan pemahaman konsep matematis siswa antara yang menerapkan model IMPROVE dengan yang menggunakan model pembelajaran langsung digunakan uji kesamaan dua rata-rata yang menghasilkan nilai uji $t_{\text {hitung }}$ untuk nilai posttest adalah 1,80. Sedangkan $t_{\text {tabel }}$ dengan tingkat kepercayaan 95\% adalah 1,68. Karena $t_{\text {hitung }}>t_{\text {tabel }}$ yaitu $1,80>1,68$, maka $\mathrm{H}_{0}$ ditolak sedangkan $\mathrm{H}_{1}$ diterima yang artinya kemampuan pemahaman konsep matematis siswa yang menggunakan model pembelejaran IMPROVE lebih tinggi daripada kemampuan pemahaman konsep matematis siswa menggunakan model pembelajaran langsung. Hal ini berarti rata-rata hasil tes kemampuan pemahaman konsep siswa yang diajarkan melalui model pembelajaran IMPROVE lebih tinggi dengan rata-rata hasil tes pemahaman konsep siswa yang diajarkan dengan model pembelajaran langsung.

\section{SIMPULAN DAN SARAN}

Dari hasil penelitian dan pembahasan yang telah dilakukan dapat disimpulakan bahwa rata-rata kemampuan pemahaman konsep matematis siswa pada materi Sistem persamaan linear dua variabel kelas eksperimen yang dibelajarkan dengan mengunakan model pembelajaran IMPROVE memperoleh nilai rata-rata 80,18 dengan simpangan baku 9,83dan kemampuan pemahaman konsep matematis siswa pada materi Sistem persamaan linear dua variabel kelas kontrol yang dibelajarkan dengan model pembelajaran langsung memperoleh nilai rata-rata 61,52 dengan simpangan baku 11,91. Hipotesisnya adalah Kriteria pengujian dari uji statistik dengan mengunakan uji-t, dimana diperoleh $t_{\text {hitung }}=1,80$ dan $t_{\text {tabel }}=1,68$. Sesuai dengan kriterian pengujian, jika $t_{\text {hitung }}>t_{\text {tabel }}$ maka $\mathrm{H}_{1}$ diterima, terdapat perbandingan kemampuan pemahaman konsep matematis pada materi Sistem persamaan linear dua variabel antar siswa yang mengunakan model pembelajaran IMPROVE dengan menggunakan model pembelajaran langsung. Ini berarti kemampuan pemahaman konsep matematis siswa pada materi Sistem persamaan linear dua variabel yang dibelajarkan dengan mengunakan model pembelajaran IMPROVE lebih tinggi dari pada pembelajaran menggunakan model pembelajaran langsung pada siswa kelas VIII SMPN 30 Muaro Jambi. 


\section{$\pi$ (Phi)}

Bagi guru mata pelajaran matematika disarankan untuk mencoba menerapkan pembelajaran menggunakan model pembelajaran IMPROVE sebagai salah satu alternatif pembelajaran di kelas. Bagi guru sebaiknya mempersiapkan pembelajaran dengan baik sehingga semua langkah yang terdapat pada Rencana Pelaksanaan Pembelajaran (RPP) dapat dilaksanakan secara optimal. Dalam pembelajaran, guru perlu melihat perkembangan belajar siswa dalam setiap kelompok. Agar waktu yang digunakan lebih efisien dan guru dapat membantu siswa secara optimal, apabila dalam beberapa kelompok mengalami kesulitan pada bagian yang sama maka guru dapat membantu semua kelompok secara langsung di depan kelas. Penelitian ini hanya dilakukan pada materi sistem persamaan linear dua variabel dengan model pembelajaran IMPROVE diharapkan pada penelitian selanjutnya dapat melaksanakan penelitian yang serupa pada materi yang berbeda, untuk mengukur aspek yang lain atau jenjang sekolah yang berbeda.

\section{DAFTAR PUSTAKA}

Arikunto, Suharsimi. 2013. Prosedur Penelitian Suatu Pendekatan praktik. Jakarta: Rineka Cipta

Fitriani, S. (2015).1. Perbandingan

Hasil Belajar Matematika Siswa Dengan Menerapkan Strategi Pembelajaran Aktif Tipe PracticeRehearsal Pairs dan Action Learning di Kelas VIII SMP Negeri 16 Kota Jambi: Ekotrans. 15 (1), 91-102.

Huda, Miftahul. 2014. Model-Model Pengajaran dan Pembelajaran. Yogyakarta: Pustaka Pelajar

Lestari, E.K, 2015. Penelitian Pendidikan matematika. Bandung: PT Refika Aditama

Riduwan. 2014. Pengantar Statistika. Bandung: Alfabeta

Rusman. 2015. Pembelajaran tematik terpadu Teori, Praktik dan penilaian. Jakarta: Rajawali

Sagala, Syaiful, 2013. Konsep Dasar dan Makna Pembelajaran. Bandung: Alfabeta

Shoimin, Aris, 2014. 68 Model Pembelajaran Inovatif dalam Kurikulum 2013. Yogyakarta: Arruzz Media

Sudjana. 2009. Metode Statistika. Bandung: Tarsinto

Sugiyono. 2015. Metode Penelitian Pendidikan Pendekatan Kuantitatif, Kualitatif, dan RND. Bandung: Alfabeta 